\title{
Developing an Attitude Scale for Turkish Sign Language (TSL-AS)
}

\author{
Hatice Cansu Bilgiç \\ Special Education Department, Gazi University, Ankara, Turkey \\ ORCID: 0000-0002-6006-0000 \\ Cem Aslan* \\ Special Education Department, Gazi University, Ankara, Turkey \\ ORCID: 0000-0002-0300-5873 \\ Merve Özdemir Kılıç \\ Special Education Department, Gazi University, Ankara, Turkey \\ ORCID: 0000-0002-1768-0095
}

\section{Adnan Kan}

Division of Guidance and Psychological Counseling, Gazi University, Ankara, Turkey, ORCID: 0000-0002-3610-0033

Article history

Received:

27.05.2020

Received in revised form: 20.07.2020

Accepted:

20.07.2020

Key words:

Turkish sign language

Attitude

Hearing impaired

Special education
In this study, the aim is to develop a measurement tool that can be used to measure attitudes towards Turkish Sign Language (TSL). For this purpose, the researchers followed a systematic process. The study group consists of students in the special education departments of three different universities' faculties of education in the spring semester of the 2019-2020 academic year. The developed scale was applied to 510 students in total. The scale data obtained from the students were randomly divided into two; Exploratory Factor Analysis (EFA) was performed with the first group data $(\mathrm{n} 1=297)$, and Confirmatory Factor Analysis (CFA) was performed with the second group data $(n 2=213)$. Within the scope of the results obtained from EFA, it was determined that the scale consists of four factors (effort, necessity, avoidance, active use) and 20 items. When the obtained construct validity was tested with CFA, it was seen that the values of fit indexes were at an acceptable level. The internal consistency of the scale was calculated with Cronbach's Alfa and the result obtained from this data set was determined as .91 . The reliability coefficients of the factors ranged from .70 to .90 . Findings showed that the scale is valid and reliable to measure attitudes towards TSL.

\footnotetext{
*Correspondency: cemaslan@gazi.edu.tr
} 


\section{Introduction}

Language is a system consisting of mutually compromised symbols that people use for various purposes such as communicating, obtaining information, and expressing requests (Topbas, 2003; Uzuner, 2003). The symbols that make up this system can be auditory or visual depending on the features of the language (Girgin \& Kemaloglu, 2017; Kubus, Ilkbasaran \& Gilchrist, 2016). This system consists of two fundamental components: The receptive and the expressive language. The receptive language, which is the first component, (Cengiz, Yayan, Ercan, Kolcu \& Akgul, 2016) covers the perception of external symbols, performing what is said, and listening skills; the second component, expressive language, is expressed as the sum of the individual's responses to express themselves (Senay, 2004).

The vast majority of the society uses verbal language as a means of conveying their thoughts. Individuals with normal (typical) development can internalize the structure of their own language in a short time because they can receive and process the visual and auditory stimuli in the environment. With this aspect, the sense organs play an important role in the development of language and speech skills (Akcamete, 1993). On the contrary, for the hearing-impaired individuals, who have difficulty in perceiving voice stimuli, the perception and use of the language spoken around can be negatively affected (Akcamete, 1993; Tufekcioglu, 2001). In order for the hearing-impaired individuals to interact with the environment, show academic development, express themselves, and compensate for the negative situations in question, a communication model should be determined taking into account the level of disability, the age, and the support received (Cengiz et al., 2016; Girgin, 2006; Most, Aram \& Andorn, 2006). One of these models, which are classified as verbal or non-verbal, is sign language.

Sign language is one of the communication methods used by hearing-impaired individuals who have severe hearing impairment and suffer from late diagnosis, use of inappropriate devices and lack of special education support. In cases where the individual cannot use or learn verbal language, sign language, which enables the transfer of thoughts, has an important role in terms of both personal development and social acceptance (Pistav Akmese \& Kayhan, 2017). In this regard, sign language can enable hearing-impaired individuals who have not acquired the verbal language to be in contact with the society and to develop academically and intellectually (Kemaloglu, 2014; Kubus et al., 2016; Yaprak-Kemaloglu, 2016). In the literature (e.g., Goodwyn, Acredolo \& Brown, 2000; Gol Guven, 2016; Moore, Acredolo \& Goodwyn, 2001; Pistav Akmese \& Kayhan, 2016), it has been shown that the use of sign language positively affects the hearing impaired individuals' social, emotional, and cognitive development.

Sign language is expressed as a language created with all body movements, primarily hand movements, facial expressions, and gestures, and based on visual symbols (Arik, 2016; Girgin \& Kemaloglu, 2017; Pistav Akmese \& Kayhan, 2017). Although it has a different grammar and sentence structure from speech-based languages, it is unique to the country it is in, just like verbal languages. In this respect, it can be said that each country has a sign language that contains its own language features and cultural elements (Kemaloglu, 2014; Stokoe, 2005). Sign language has a significant similarity to the verbal language of the country but can differ in areas such as grammar and sentence structure (Kemaloglu, 2014). For example, in verbal language, new and meaningful words can be produced by changing the sounds in the word, whereas in sign language, 
each new word is expressed with a different sign (Is1kdogan Ugurlu, 2017).

Turkish Sign Language (TSL) has been taught in $1^{\text {st }}, 2^{\text {nd }}$, and $3^{\text {rd }}$ grades of primary schools for the hearing impaired since 2016-2017 academic year in our country. Especially in educational environments, sign language is used to support the development of students with limited or no speech development. It is stated that these individuals prefer to use sign language in their daily lives and at the school, even if they use the spoken language limitedly (Gurboga \& Kargin, 2003; Parlak, 2011). It is important for teachers (e.g. special education teachers, field teachers) working with students who have limitations in verbal language acquisition to learn sign language (Pistav Akmese \& Kayhan, 2017; Ting \& Gilmore, 2012). Accordingly, TSL, which was a compulsory course in the teaching program for the hearing impaired in the 20142015 academic year for the first time, was also included in special education teaching undergraduate programs with an arrangement made in the 2016-2017 academic year (Ministry of National Education, 2016). Thus, it is aimed that pre-service teachers, who can work at different levels of special education, gain awareness about sign language, and learn TSL. However, the ability of prospective teachers to transfer their experiences and knowledge about sign language into the service is directly related to the quality of the education they receive and their attitudes towards sign language (Alamri, 2017; Ting $\&$ Gilmore, 2012). The fact that teachers have information about the needs of hearingimpaired students and educate themselves in line with these needs improves their attitudes towards students positively (e.g. Jarvis \& Iantaffi, 2006, Sar1, 2007).

Attitude is expressed as an individual's reactions that include beliefs, thoughts or actions against an object, event, or person around (Aronson, Wilson \& Akert, 2012; Inceoglu, 2010). Attitudes are obtained with experiences, have a dynamic form and a holistic structure that includes affective, cognitive, and behavioural dimensions (Aronson et al., 2012; Karasar, 2009). Affective dimension is based on emotions and values; cognitive dimension is based on factual knowledge and beliefs; and behavioural dimension is based on the tendency to behave positively or negatively (Arkonac, 2001; Kan, 2007; Tavsanc1l, 2010). In this respect, attitude can affect people's decisionmaking processes and direct their behaviour (Ulgen, 1996). For example, having a positive attitude towards an object may lead to the development of the desire to interact with that object and the acceptance and belief towards the object. Therefore, it can directly or indirectly affect the goals that the individuals try to reach and the importance they attach to events or individuals (Kagitcibasi, 2012). As it has the feature of affecting the behaviour of the individual, measuring attitudes regarding the targeted object or event is a desired act (Erkus, 2003; Morgan, 1991). That being said, attitudes can be indirectly measured because they contain a complex mental process that underlies the behaviour (Ozbay, Bagc1 \& Uyar, 2008).

There are studies in the literature that have determined attitudes towards hearingimpaired individuals (e.g., Cambra, 2002; Cooper, Rose \& Mason, 2004; Coryell, Holcomb \& Scherer, 1992; Haug \& Hintermair, 2011; Lee \& Pott, 2018; Ting \& Gilmore, 2012). In these studies, the experience, knowledge, and attitude characteristics of specialists, teachers, and students working with hearing-impaired students were examined with methods such as questionnaires and interviews. Clark, Barker Choi \& Allen (2013) developed a scale to determine attitudes towards the education of hearingimpaired individuals. This scale, which consists of four factors such as hearing technologies, literacy through visual language and bilingualism, listening and spoken 
language, and difficulties faced by parents in the education of sign language, serves to measure the attitudes of individuals with regard to hearing impaired students and the language they use. In addition, it is observed that attitudes towards sign language have also been examined (e.g. Alamri, 2017; Bayley, Hill, McCaskill \& Locas, 2017; Brightman, 2013; Gold-Schmidt, 2000; Hill, 2012). It is seen that attitudes towards sign language have both been taken as a direct variable and examined in sub-dimensions. For example, Gold-Schmidt (2000) investigated the attitudes of individuals who are normally hearing but whose parents have hearing impairment and hence use sign language towards the German Sign Language. Hill (2012) dealt with attitudes towards American Sign Language (ASL). In another study, Bayley et al. (2017) investigated the attitudes of African Americans towards the sign language they use themselves and of those using ASL. In addition, there are studies examining the attitudes of individuals who use sign language actively and those who teach and learn sign language (e.g., Alamri, 2017; Brightman, 2013; Pistav Akmese \& Kayhan, 2017). For instance, Brightman (2013) studied the attitudes of participants who took courses on sign language during university education towards ASL and hearing-impaired students. In the study of Alamri (2017), the attitudes of teachers working with hearing-impaired students in Saudi Arabia towards the Sign Language of Saudi Arabia were evaluated. In our country, the opinions of prospective teachers attending sign language lessons were obtained by Pistav Akmese \& Kayhan (2017) regarding TSL education. The research was conducted with a semi-structured interview and its findings were analyzed descriptively.

Sign language has a structure that covers the cultural values of the country where it is used. While there are attitude scales in the international literature for sign languages used in the relevant countries, in Turkey, there is no comprehensive measurement tool that can quantitatively measure attitudes towards sign language. It can also be stated that there is limited knowledge in literature on attitudes towards sign language. Thereupon, it is possible to talk about a need. In this study, it was aimed to develop a measurement tool capable of measuring attitudes towards TSL. At this point, this study is expected to contribute to the literature and be a source measurement tool for researchers planning to work on this issue.

\section{Method}

\section{Participants}

This study was carried out with undergraduate students studying in special education teaching programs within universities' faculties of education. Participating students continue their education at three different universities (Table 1) in the spring semester of the 2019-2020 academic year. The study included 510 students in total. The age range of the students participating in the study is between 17 and 38, and the average age is 21. Participants' information regarding gender, department, university, and the status of taking a sign language course and attending any course related to sign language is presented in Table 1. 
Table 1. Study group.

\begin{tabular}{|c|c|c|c|}
\hline & & $\mathrm{f}$ & $\%$ \\
\hline \multirow{2}{*}{ Gender } & Female & 317 & 62.2 \\
\hline & Male & 193 & 37.8 \\
\hline \multirow{3}{*}{ Department } & Education of The Visually Impaired & 71 & 13.9 \\
\hline & Education of Intellectual Disability & 142 & 27.8 \\
\hline & Special Education Teaching & 297 & 58.2 \\
\hline \multirow{3}{*}{ University } & Gazi University & 263 & 51.6 \\
\hline & Ankara University & 136 & 26.7 \\
\hline & Necmettin Erbakan University & 111 & 21.8 \\
\hline \multirow{2}{*}{ Taking any TSL course } & Yes & 261 & 51.2 \\
\hline & No & 249 & 48.8 \\
\hline \multirow{2}{*}{$\begin{array}{l}\text { Attending any course related to } \\
\text { TSL }\end{array}$} & Yes & 209 & 41.1 \\
\hline & No & 301 & 58.9 \\
\hline
\end{tabular}

\section{Development of the Item Pool and Scale Form}

While developing the Attitude Scale for Turkish Sign Language (TSL-AS), in the first stage, literature review was carried out in order to establish a theoretical framework. Accordingly, studies on the hearing-impaired individuals and sign language in the literature (e.g., Alamri, 2017; Bayley et al., 2017; Brightman, 2013; GoldSchmidt, 2000; Hill, 2012) were examined by the researchers. Later, they gathered information about the statements, dimensions (factor), and theoretical framework that can take place in TSL-AS. Afterwards, statements / items that could be included in TSL-AS began to be written. While writing these, an item pool was created. To that end, whilst creating the item pool of TSL-AS, the cognitive, affective and behavioural dimensions and the three-component theoretical structure of the attitude (Erkus, 2012; Reid, 2006) were taken into consideration. In this context, researchers created an item pool containing 53 items. Of these items, 19 are cognitive, 18 are affective, and 16 are behavioural.

In the research, expert opinion was taken in order to ensure the content validity of TSLAS. This method is one of the methods frequently used in determining the construct validity that expresses the qualitative and quantitative adequacy of the items created for the properties to be measured (Buyukozturk, 2015; Fraenkel \& Wallen, 2003). In this context, a 53-item scale form was sent to seven experts (faculty members: two assessment and evaluation experts, four special education experts, and one Turkish education expert) who received it via e-mail. The experts were asked to evaluate the items and statements $(n=53)$ in the scale form in terms of "appropriateness". In this context, an Expert Opinion Form was prepared to serve the two-category evaluation by adding "appropriate", "inappropriate ", "explanations and suggestions" columns for each item in the scale form. This form was sent to experts and opinions were received. Experts conveyed their opinions and suggestions regarding the scale form to the researchers via e-mail again.

In line with the feedback obtained from the experts, some items with low intelligibility and multiple judgments were excluded from the scale form, some that were stated to overlap were combined, and some that did not contain attitude statements were reviewed. The scale form, which was prepared as 53 items, was reduced to 31 items as a result of expert opinions. Twenty of these items were positive and 11 were negative. In order to perform data analysis of the scale, the final version, which is a 31-item scale 
form, was used. In this context, it was decided by the researchers to prepare the scale as 5-point Likert. The scale form was scored as "Totally Disagree (1), Disagree (2), Undecided (3), Agree (4), Totally Agree (5)".

\section{Data Collection}

The data of the study were collected from the undergraduate students of the education faculties of three state universities in two cities, Ankara and Konya. In the data collection process, the developed scale form was applied to students. In this process, the researchers collected the data in two different ways. The first is that researchers directly apply scale forms in their application environment. In this context, the researchers went to universities in Ankara to collect data and applied their scale forms. Students were informed about the purpose of the study and the subject of the scale. Later, students who volunteered to participate in the study were asked to fill out scale forms. The researchers applied the scale in classes in accordance with the permission of the lecturer responsible for the lesson, taking into consideration the hours of the lesson when students were all present. The second method is to send the scale form to the application environment by post and / or cargo and apply with the help of another instructor. In this context, the scale form was sent to the lecturer at the university in Konya. Here, the instructor who received the scale forms requested the students to fill out the scale form by making the necessary explanations about the purpose of the study and the subject of the scale. The completed scale forms were sent to the researchers again by mail / cargo. In the data collection phase, it took an average of 10 minutes to complete a scale form, and all data of the study were collected in 33 days (February 10-March 13, 2020). During this period, 510 students were reached, and the data collection process was terminated considering that this number was sufficient for validity and reliability analysis.

\section{Data Analysis}

All data collected from students were transferred to SPSS 21.0 package program for statistical analysis of validity and reliability. Before starting the data analysis, the outlier, missing and extreme values in the filled scale forms $(n=510)$ were corrected. Then the scores of negative statements $(n=11)$ in the scale (TSL-AS) were reversed. As a result of this process, validity and reliability analyses were performed in line with the responses of 510 students who participated in the study and filled out the scale form. According to the literature, Exploratory Factor Analysis (EFA) and Confirmatory Factor Analysis (CFA) are suggested to be performed on different groups (Worthington \& Whittaker, 2006). In this regard, students were divided into two subgroups with the help of random group assignment feature in the SPSS program. As a result, EFA was performed with the scale data obtained from 297 students and CFA was performed with the data obtained from 213 students.

In the study, EFA was performed to reveal similar characteristics between the variables of TSL-AS, to establish the evidence of construct validity, and to reveal the factor structure (Cohen, Manion \& Morrison, 2011; Cokluk, Sekercioglu \& Buyukozturk, 2010). EFA is one of the statistical techniques commonly used in the field that makes the variables that are related to each other independent factors according to their similar characteristics (Tavsanc1l, 2010). In the study, the suitability of scale data obtained from students for factor analysis was first tested before performing EFA. For this purpose, Kaiser-Meyer Olkin (KMO) and Bartlett's Test of Sphericity tests were examined. 
Following the determination of the suitability of the data for factor analysis, the promax rotation was applied so as to reveal the distribution of factor loads more clearly based on the size of the data set and considering the relationship between the factors (Altunısık, Coskun, Y1ldırım \& Bayraktaroglu, 2010, Erkus, 2003). As a result of the EFA performed using the promax rotation, the factor number of the scale and the distribution of the items in the scale according to the factors were determined. CFA, on the other hand, is the statistical method used to determine the level of representation of the variable groups in the factor structure revealed as a result of AFA (Cokluk et al., 2010; Tabachnick \& Fidell, 2001; Wetson \& Gore, 2006). CFA applied in the study was conducted with LISREL 9.2 program. The structure of the scale was evaluated by examining the fit indexes together with the results obtained from CFA. In order to test the reliability of the scale, the item-total correlation of the items and the Cronbach's Alpha reliability coefficient were examined. Cronbach's Alpha reliability coefficient was calculated separately for each factor and for the whole scale.

\section{Results}

\section{Exploratory Factor Analysis (EFA)}

According to the literature on the scale development studies, with the condition of having not less than 100 participants, the sample size should be between 5 and 10 times the number of items for which factor analysis will be applied (Bryman \& Cramer, 1999; Gorsuch, 1990; Tavsanc1l, 2010). In the current study, EFA for TSL-AS was performed on data obtained from 297 students. Thence, it would be fair to state that this number adequately meets the sample size recommended by the literature.

Whether the data are suitable for factor analysis is decided according to the KMO Coefficient and Bartlett's Test of Sphericity results (Cokluk et al., 2010; Karagoz \& Kosterelioglu, 2008). In this regard, the Bartlett Sphericity Test result should be statistically significant and the KMO value should be greater than 0.50 . In the literature, 0.60 is expressed as medium, 0.70 good, 0.80 very good, 0.90 perfect for KMO value (Bryman \& Cramer, 1999; Kahyaoglu, 2011; Leech, Barrett \& Morgan, 2005; Seker, Deniz \& Gorgen, 2004). Bartlett's Test of Sphericity result and KMO values of TSL-AS are given in Table 2.

Table 2. Bartlett sphericity test result and KMO values.

\begin{tabular}{lll}
\hline Kaiser-Mayer-Olkin (KMO) & & .880 \\
\hline \multirow{3}{*}{ Bartlett's Test of Sphericity } & Chi-square $\left(\mathrm{x}^{2}\right)$ & 3452.176 \\
& $\mathrm{Sd}$ & 465 \\
& $\mathrm{p}(\mathrm{p}<0.05)$ & .000 \\
\hline
\end{tabular}

When Table 2 is examined, it is seen that the obtained KMO value is .880. Bartlett's Test of Sphericity result was found to be statistically significant. According to the literature, if the significance value of Bartlett's Test of Sphericity is less than 0.05, it is stated that this test is meaningful and suitable for factor analysis (Field, 2009). In this case, it can be said that the data obtained in the study are suitable for factor analysis. Bartlett's Test of Sphericity indicates whether the relationship between variables is sufficient. If the $\mathrm{p}$ value is less than 0.05 significance level, it indicates that there is a sufficient relationship between the variables for factor analysis. 


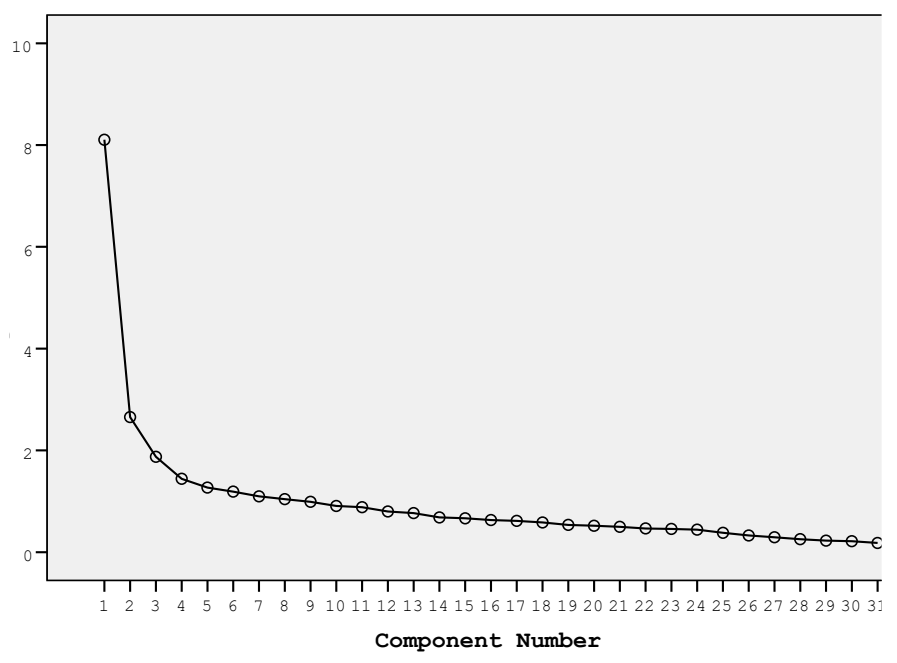

Figure 1. Scree plot.

EFA was performed on all items $(n=31)$ included in the scale form (TSL-AS). In this context, the factors created by the items, and the items collected under these factors were revealed. For this, particularly the eigenvalues of the items were examined (Gelbal, Duyan \& Ozturk, 2008). When the EFA result was analyzed, 31 items gathered under eight factors whose eigenvalues were greater than one and explained $60.23 \%$ of the total variance. In the literature, it is stated that when determining the factors, it is necessary to look at the eigenvalue of the item and the item loadings and the minimum cut-off points of the factor loadings (Field, 2009; Hair, Black, Babin, Anderson \& Tatham, 1998). When the load values of the items were examined, 12 items whose item value was below .30 and did not load any item or loaded on more than one factor were removed from TSL-AS. As a result of the repeated EFA over the remaining 19 items, the minimum cut-off point of factor loadings was taken as .40 and it was observed that TSL-AS gathered under four factors whose eigenvalue were greater than one. The items that make up each factor, the factor loadings, and the total variance values they explain are detailed in Table 3.

Table 3. EFA results of TSL-AS.

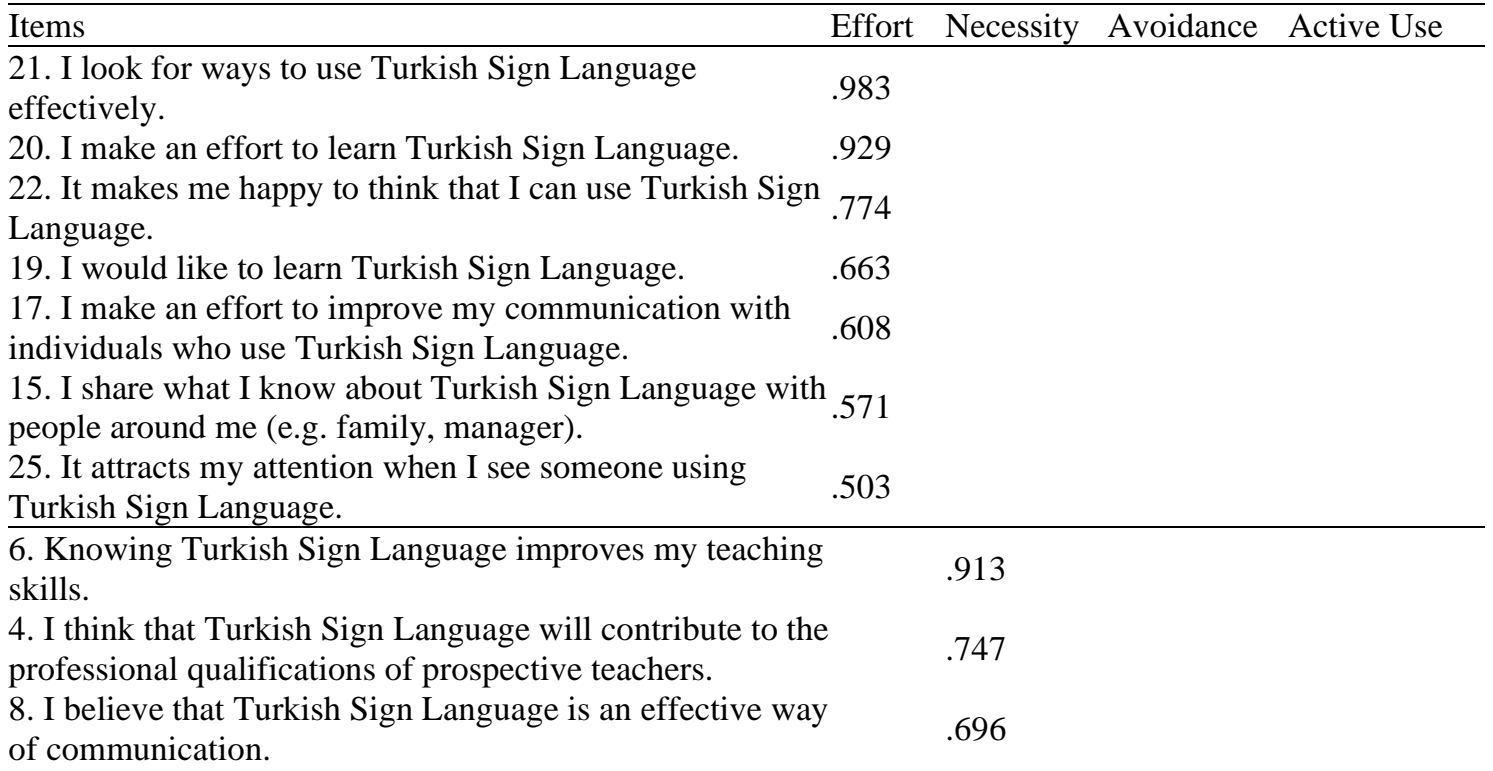


9. I think that prospective teachers / teachers of special education should learn Turkish Sign Language.

7. As a prospective teacher, I do not believe that Turkish Sign Language is important to me.

24. Technological developments related to Turkish Sign

Language (e.g. web applications, internet) do not interest me.

28. I worry when I think I will use Turkish Sign Language.

16. I am not in an environment where Turkish Sign

Language is used (e.g. meeting, school) unless I have to.

14. I do not recommend individuals around me (e.g. family, friend, manager) to learn Turkish Sign Language.

11. I follow the sources for Turkish Sign Language (e.g. books, magazines, news).

13. I make friends who know Turkish Sign Language.

12. I encourage those around me (e.g. student, friend) to learn Turkish Sign Language.

\begin{tabular}{lllll}
\hline Eigenvalues & 6.168 & 1.962 & 1.458 & 1.243 \\
Explained Variance (\%) & 32.461 & 10.326 & 7.672 & 6.540 \\
\hline
\end{tabular}

As a result of EFA, the contribution of the variance formed by the factors to the total variance is considered to be important, but it is stated that this contribution should be at least 50\% (Buyukozturk, 2015; Thompson, 2004). In addition, according to Tabachnick \& Fidel (2001), if the factor load of an item is above 0.71, it is "excellent"; if it is above 0.63 , it is "very good"; if it is above 0.55 , it is "good"; if it is above 0.45 , it is mediocre; and if it is above 0.30, it is considered "weak". Buyukozturk (2015) states that factor loading values having a value of 0.45 and above will represent an ideal result. When the EFA results stated in Table 3 were analyzed in terms of all these variables, it was found that the 19 items in TSL-AS gathered in four factors with the eigenvalue that is higher than one and explained $56.99 \%$ of the total variance. In this context, it can be stated that the obtained findings meet the recommended values for the total variance and item factor loadings accepted in the literature.

When Table 3 is examined, seven items $(21,20,22,19,17,15,25)$ in TSL-AS gathered under the first factor; five items $(6,4,8,9,7)$ under the second; four items $(24,28,16,14)$ under the third; three items $(11,13,12)$ under the fourth. The factor loading values of the items in TSL-AS are between .41 and .98 . Factor loadings vary between .50 and .98 in the first factor; between .41 and .91 in the second factor; between .49 and .78 in the third factor; and between .65 and .78 in the fourth factor.

As a result of the analysis, each factor in TSL-AS was given a name. In this context, naming was done considering the meanings of the items collected under the factors. For this reason, the items under each factor were re-examined in the naming of the factors. Accordingly, the first factor that includes items related to the willingness to learn TSL was named as "effort"; the second factor containing items related to the advantages of using TSL as "necessity"; the third factor consisting of items that reflect negative statements about TSL as "avoidance"; and the fourth factor, which consists of items containing some actions for the use of TSL as "active use". The findings of the analysis showing the factors in TSL-AS and their relationships are shown in Table 4. 
Table 4. Correlation coefficients among factors.

\begin{tabular}{lllll}
\hline Factors & Effort & Necessity & Avoidance & Active Use \\
\hline Effort & 1.000 & .531 & .416 & .156 \\
Necessity & .531 & 1.000 & .355 & .520 \\
Avoidance & .416 & .355 & 1.000 & .570 \\
Active Use & .156 & .520 & .570 & 1.000 \\
\hline
\end{tabular}

Correlation values above .25 between the factors are considered as "significant" (Garson, 2009). As seen in Table 4, inter-factor relationships have statistically significant correlation values.

\section{Confirmatory Factor Analysis (CFA)}

According to the data obtained from EFA, a model consisting of 4 factors and 19 items emerged. The construct validity of this model was tested with CFA. The suitability of the model presented in this context was examined according to fit indexes $\chi^{2 / \mathrm{df}}$ (Chi-Square / Degree of Freedom), RMSEA (Root Mean Square Error of Approximation), GFI (Goodness of Fit Index), SRMR (Standardized Root Mean Square Residual), AGFI (Adjusted Goodness of Fit Index), CFI (Comparative Fit Index), and NFI (Normed Fit Index) values (Secer, 2013). Accordingly, the structure emerging without any modification process in the model according to the applied CFA result is presented in Figure 2. The fit index values obtained at the same time are as follows: $\left[\chi^{2 /}\right.$ $\mathrm{df}=4.77(\mathrm{p}=.000) ; \mathrm{RMSEA}=0.086 ; \mathrm{NFI}=0.92 ; \mathrm{CFU}=0.94 ; \mathrm{AGFI}=0.84 ; \mathrm{GFI}=$ $0.87 ; \mathrm{SRM}=0.079]$.

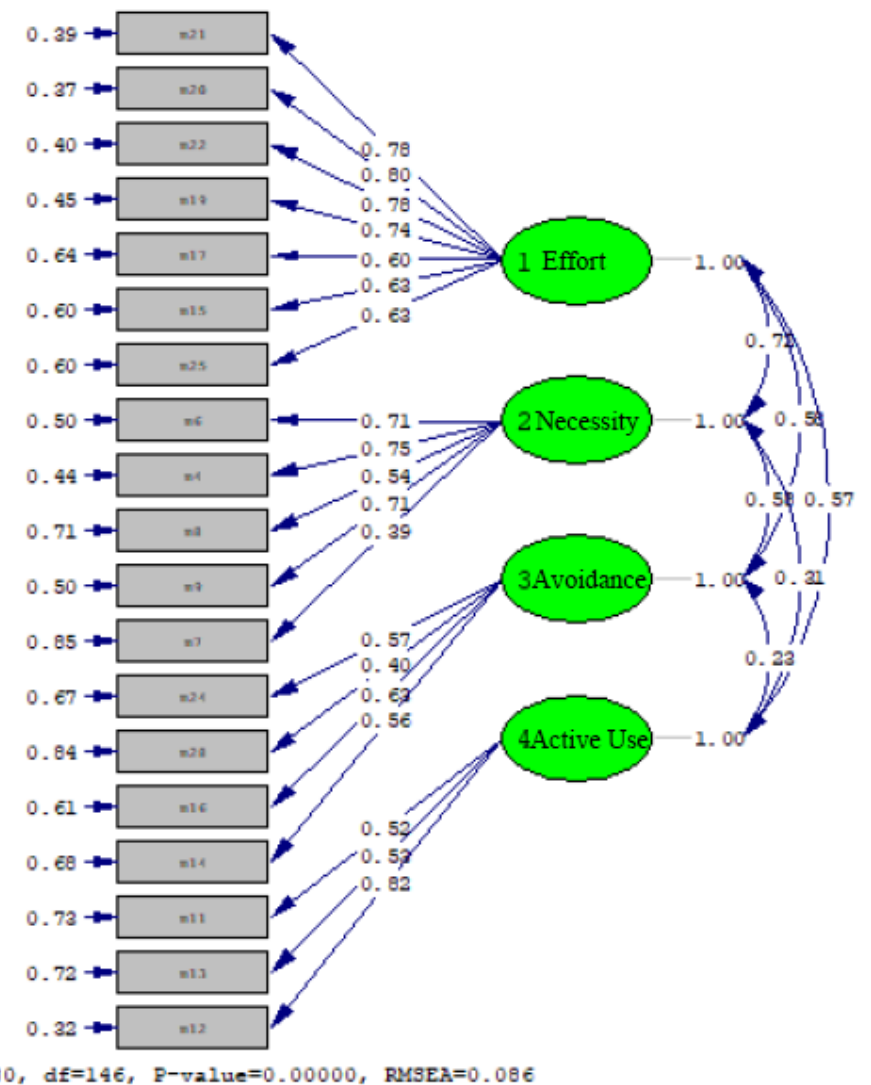

Figure 2. Path diagram before modification.

In the study, it was determined that there were some suggestions for modification among some items according to CFA result. The modifications proposed by the 
researchers were examined and some modifications were applied to the model, considering that a latent relationship between the two items was acceptable. Modifications were made among the items that were thought to provide the highest contribution to the model. In this regard, the modification process was applied among the items included in the first factor (effort). These items are 21 and 20, and 22 and 19. The final structure of the model that emerged after the modification process is given in Figure 3.

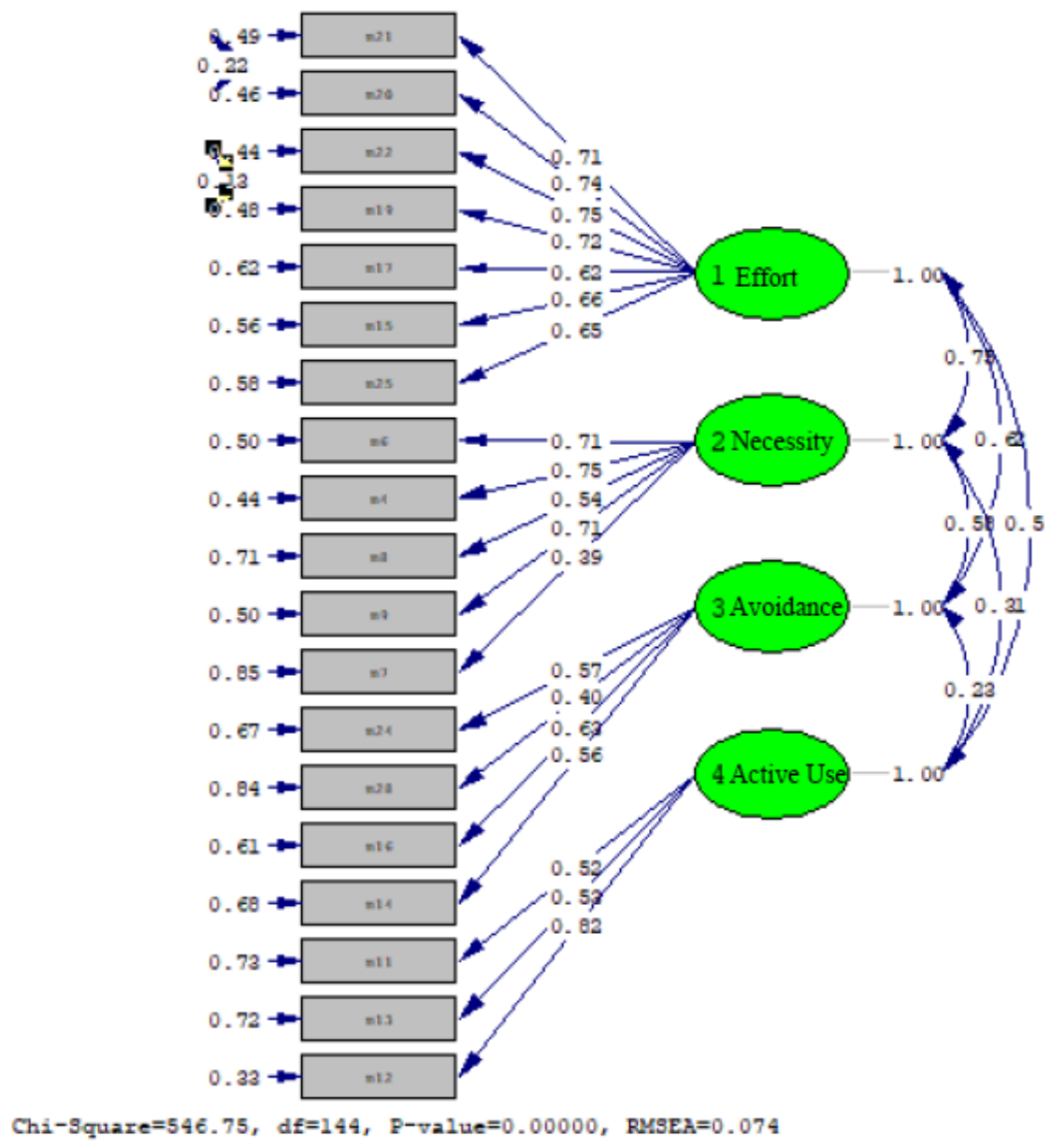

Figure 3. Path diagram after modification.

Information about the model including the fit index values, good fit values, and acceptable fit values (Schermelleh-Engel, Moosbrugger \& Muller, 2003) and fit status are given in Table 5. Accordingly, when Table 5 is examined, RMSEA value appears to be 0.074. RMSEA value between 0.050 and 0.080 indicates that the model has an acceptable index (Brown, 2006). It is seen that the fit index of the model is at an acceptable level according to the current RMSEA value. When the SRMR value is analyzed, it is seen that the aforementioned value is 0.062 . When other fit indexes are considered, it is witnessed that GFI is 0.90 and AGFI is 0.87. When SRMR, GFI, and AGFI values are examined, it is observed that they are at an acceptable level of fit and the model is in acceptable fit (Kline, 2005; Varinli, Yaras \& Basalp, 2009).

The fit indexes of the model obtained from CFA that was applied for construct validity were examined and it was found that the chi-square value $\left(x^{2} / \mathrm{df}\right)=3.79(\mathrm{p}=.000)$, $\mathrm{sd}=144, \mathrm{p}=.000$ ) of TSL-AS was significant. It can be said that this value indicates an acceptable fit. 
Table 5. Fit indexes.

\begin{tabular}{|c|c|c|c|c|}
\hline Fit Indexes & Good Fit Value Range & $\begin{array}{l}\text { Acceptable Fit Value } \\
\text { Range }\end{array}$ & $\begin{array}{l}\text { Current } \\
\text { Value }\end{array}$ & Fit Status \\
\hline RMSEA & $0.00<$ RMSEA $<0.05$ & $0.05<$ RMSA $<0.10$ & 0.074 & Acceptable \\
\hline SRMR & $0.00<$ SRMR $<0.05$ & $0.05<\mathrm{SRMR}<0.10$ & 0.062 & Acceptable \\
\hline GFI & $0.95<\mathrm{GFI}<1.00$ & $0.90<\mathrm{GFI}<0.95$ & 0.90 & Acceptable \\
\hline AGFI & $0.90<\mathrm{AGFI}<1.00$ & $0.85<\mathrm{AGFI}<0.90$ & 0.87 & Acceptable \\
\hline CFI & $0.95<\mathrm{CFI}<1.00$ & $0.90<\mathrm{CFI}<0.95$ & 0.95 & Acceptable \\
\hline NFI & $0.95<\mathrm{NFI}<1.00$ & $0.90<\mathrm{NFI}<0.95$ & 0.93 & Acceptable \\
\hline
\end{tabular}

Source: (Schermelleh-Engel, K., Moosbrugger, H., \& Muller, H. 2003

\section{Item Analysis and Reliability}

One way to determine the item analysis of the scales is the item analysis technique based on the difference of the lower and upper group means (Buyukozturk, 2015). Accordingly, firstly, the total points from the scale are ranked starting from the highest to the lowest, and the upper groups consisting of the highest-ranking $27 \%$, and the sub group consisting of the lowest-ranking $27 \%$ group, are determined. Then, to what extent the items distinguish individuals in terms of measured behaviour is determined by conducting independent $t$ test between the scores of the two groups (upper and lower) for each item in the scale (Tavsanc1l, 2010). Table 6 shows the independent $t$ test results for the upper and lower groups. As a result of the analysis, it was determined that the items in TSL-AS differ significantly between the $27 \%$ upper and $27 \%$ lower groups. Accordingly, it has been demonstrated that TSL-AS can distinguish students with high and low attitude scores.

Table 6. Independent $t$ test results for $27 \%$ lower and 27\% upper groups.

\begin{tabular}{|c|c|c|c|c|c|c|c|c|}
\hline \multirow{2}{*}{ Factor } & \multirow{2}{*}{ Item } & \multicolumn{2}{|c|}{ 27\% Lower Group } & \multicolumn{2}{|c|}{$\begin{array}{l}27 \% \text { Upper } \\
\text { Group }\end{array}$} & \multirow{2}{*}{ sd } & \multirow{2}{*}{$\mathrm{t}$} & \multirow{2}{*}{ p. } \\
\hline & & $\bar{x}$ & S.S. & $\bar{x}$ & S.S. & & & \\
\hline \multirow{7}{*}{ Effort } & 21 & 2.9638 & 1.18019 & 4.8551 & .42804 & 274 & -17.698 & .000 \\
\hline & 20 & 3.1159 & 1.23260 & 4.9348 & .24781 & 274 & -16.994 & .000 \\
\hline & 22 & 3.4783 & 1.17279 & 4.9565 & .23768 & 274 & -14.512 & .000 \\
\hline & 19 & 3.4928 & 1.20368 & 4.9493 & .25120 & 274 & -13.915 & .000 \\
\hline & 17 & 2.7681 & 1.10268 & 4.6232 & .69621 & 274 & -16.711 & .000 \\
\hline & 15 & 2.6594 & 1.27007 & 4.8116 & .44477 & 274 & -18.787 & .000 \\
\hline & 25 & 3.5725 & 1.17695 & 4.9203 & .32107 & 274 & -12.979 & .000 \\
\hline \multirow{5}{*}{ Necessity } & 6 & 3.3261 & 1.22720 & 4.8768 & .39064 & 274 & -14.145 & .000 \\
\hline & 4 & 3.6377 & 1.11357 & 4.8841 & .45325 & 274 & -12.178 & .000 \\
\hline & 8 & 3.5000 & 1.16048 & 4.7391 & .59566 & 274 & -11.159 & .000 \\
\hline & 9 & 3.4710 & 1.20335 & 4.9783 & .14636 & 274 & -14.606 & .000 \\
\hline & 7 & 3.8768 & 1.23485 & 4.8478 & .70351 & 274 & -8.026 & .000 \\
\hline \multirow{4}{*}{ Avoidance } & 24 & 3.1812 & 1.24534 & 4.5435 & .95229 & 274 & -10.208 & .000 \\
\hline & 28 & 3.2464 & 1.29464 & 4.3261 & .92146 & 274 & -7.982 & .000 \\
\hline & 16 & 3.3333 & 1.41077 & 4.8116 & .54773 & 274 & -11.475 & .000 \\
\hline & 14 & 3.6522 & 1.32165 & 4.8188 & .71721 & 274 & -9.114 & .000 \\
\hline \multirow{3}{*}{ Active Use } & 11 & 1.9275 & 1.18160 & 2.9710 & 1.19575 & 274 & -7.292 & .000 \\
\hline & 13 & 2.4275 & 1.31742 & 3.8913 & 1.04417 & 274 & -10.229 & .000 \\
\hline & 12 & 2.1449 & 1.20553 & 4.1449 & .94792 & 274 & -15.320 & .000 \\
\hline
\end{tabular}

Reliability refers to the ability of a scale to accurately measure the desired feature (Buyukozturk, 2015). Cronbach's Alpha reliability coefficient was calculated in order to be able to talk about the reliability of TSL-AS. In addition, item-total correlations were examined to show that each item in the scale was able to measure the feature it was 
intended to measure. Findings related to both measurements are given in Table 7.

Table 7. Cronbach's alpha reliability coefficient and item-total correlations.

\begin{tabular}{llllll}
\hline \multirow{2}{*}{ Factor } & Item & $\bar{X}$ & S.S. & $\begin{array}{l}\text { Corrected } \\
\text { Correlation }\end{array}$ & $\begin{array}{c}\text { Item-TotalCronbach's Alpha if Item } \\
\text { Deleted }\end{array}$ \\
\hline & 21 & 3.9094 & 1.29718 & .782 & .887 \\
& 20 & 4.0254 & 1.27182 & .774 & .888 \\
Effort & 22 & 4.2174 & 1.12324 & .770 & .889 \\
$(\alpha=.90)$ & 19 & 4.2210 & 1.13381 & .711 & .895 \\
& 17 & 3.6957 & 1.30793 & .683 & .898 \\
& 15 & 3.7355 & 1.43678 & .687 & .899 \\
& 25 & 4.2464 & 1.09419 & .680 & .898 \\
Necessity & 6 & 4.1014 & 1.19569 & .736 & .746 \\
$(\alpha=.82)$ & 9 & 4.2609 & 1.05351 & .673 & .769 \\
& 9 & 4.1196 & 1.11037 & .545 & .805 \\
& 7 & 4.2246 & 1.14109 & .627 & .781 \\
Avoidance & 28 & 4.3623 & 1.11481 & .493 & .819 \\
$(\alpha=.72)$ & 16 & 3.8623 & 1.30003 & .532 & .704 \\
& 14 & 3.7862 & 1.24519 & .448 & .626 \\
\hline Active Use & 11 & 4.0725 & 1.29972 & .579 & .671 \\
$(\alpha=.70)$ & 13 & 2.2355 & 1.21160 & .506 & .640 \\
\hline
\end{tabular}

When Cronbach's Alpha reliability coefficient is between .80 and .90 , it is considered as "highly reliable" and a value between .70 and .79 is considered "reliable" (Cohen et al., 2011). In this context, as a result of the Cronbach's Alpha calculation made to determine the reliability of TSL-AS, the overall reliability coefficient of the scale was determined as .91 . In addition, when Table 7 presenting the reliability coefficients of the factors is examined, the first factor (effort) has a reliability value of .90 , the second factor (necessity) .82, the third factor (avoidance) .72, and the fourth factor (active use) .70 .

The fact that the item-total correlations made to determine the level of serving the purpose of the scale is higher than .30 indicates that the factor, in which the relevant item is included, is able to serve the purpose of the scale significantly (Buyukozturk, 2015; Tavsanc1l, 2010). According to the reliability analysis, the item total test correlations vary between .448 and .782 . These results can be interpreted as that all items in TSL-AS serve the purpose of measurement.

\section{Discussion and Conclusion}

In this study, the aim is to develop a measurement tool that can determine the attitudes towards TSL. For this purpose, a 31-item scale form, of which the steps were described in the method section, was created. This scale form was applied to 510 undergraduate students studying in the special education program, and data to serve the validity and reliability analysis were obtained. In this context, the suitability of the data for factor analysis was evaluated by applying KMO and Bartlett's Test of Sphericity. Then, EFA was performed for the construct validity of the scale to be developed. As a result of the EFA, a structure consisting of four factors (effort, necessity, avoidance, active use) and 19 items, which explains $56.99 \%$ of the total variance, was reached. It can be said that the variance value explained by the scale coincides with the total 
variance accepted in the literature (Buyukozturk, 2015; Thompson, 2004). In the study, it was also aimed to verify the model reached with EFA by performing CFA. Accordingly, as a result of the conducted CFA, the model in question has been found to meet the eligibility criteria (RMSEA, GFI, SRMR, AGFI, CFI, NFI) at an acceptable level. Thus, it can be stated that TSL-AS has a valid structure. In the study, reliability values, which are expressed as the ability of a scale to accurately measure the desired feature (Buyukozturk, 2015), were also examined. For this, Cronbach's Alpha reliability coefficient was calculated. As a result, the reliability coefficient for the overall scale was determined as .91. In terms of factors, effort is .90, necessity .82, avoidance .72 and active use .70. Reliability coefficients show that TSL-AS is within acceptable values and can measure the desired feature reliably (Cohen et al., 2011).

Attitude is the tendency of individuals to reflect their behavior in the form of accepting or rejecting a person or an object (Kan \& Akbas, 2005). In this context, a measurement tool containing the components of the attitude can provide foresight about situations such as teachers' and prospective teachers' accepting or rejecting the education of sign language, including or not including sign language in their work experience. It can be said that there is no comprehensive measurement tool within the scope of the national literature that can quantitatively measure attitudes towards sign language. It is also seen that there are no measurement tools adapted to the Turkish population. However, in the international literature, some attitude scales regarding sign languages are found. In fact, various studies have been conducted in the international literature to identify attitudes towards the hearing-impaired and sign language (e.g. Cambra, 2002; Cooper et al., 2004; Coryell et al., 1992; Haug \& Hintermair, 2011; Lee \& Pott, 2018; Ting, 2012). Nevertheless, it is noteworthy that the data collection tools in these studies are attitude scales towards hearing-impaired individuals. It stands out that the sign language remains as a sub-dimension. In studies where sign language is considered as a dependent variable, it is seen that measurement tools covering information, competence and attitude and qualitative interview questions were used rather than scales for which validity and reliability studies were carried out (e.g., Alamri, 2017; Bayley et al., 2017; Brightman, 2013; Gold-Schmidt, 2000; Hill, 2012). Since not all components of the attitude are addressed in these studies, they can be said to be inadequate in determining attitudes towards sign language. With this study, a measurement tool that can measure attitudes of teachers, prospective teachers, educators working with students with hearing impairments, etc. towards sign language with all dimensions is provided as a contribution to the literature. Thusly, it is thought that TSL-AS, developed within the scope of the study, can measure attitudes towards sign language in a valid and reliable way.

While the highest score that can be obtained from TSL-AS is 95, the lowest score is 19. Whence, it can be stated that as the scores obtained from TSL-AS increase, attitudes will be positive. It is thought that TSL-AS can be an effective measurement tool in determining the attitudes of teachers working with hearing-impaired students and prospective teachers studying in special education teaching programs towards sign language. The use of TSL-AS can be preferred by the employment authorities in cases such as the selection and recruitment of teachers or staff who will work with the hearing-impaired students. By determining the attitudes of in-service teachers towards TSL, in-service trainings can be given to those who have a negative attitude. In addition, in further research, the relationship between prospective teachers' attitudes towards TSL and their course success can be examined. In addition, in this context, the 
relationship between the attitudes of in-service teachers towards TSL and the attitudes of hearing-impaired students using TSL towards school can be delved into.

\section{References}

Akcamete, G. (1993). İşitme engellilerde dil ve konuşma [Language and speech in hearing impaired]. Ankara Üniversitesi Ĕgitim Bilimleri Fakültesi Özel Eğitim Dergisi [Ankara University Faculty of Educational Sciences Journal of Special Education], 1(3), 2-9. doi:10.1501/ozlegt_0000000013

Alamri, G. (2017). Teachers' beliefs and attitudes about saudi Arabia Sign Language. (Unpublished doctoral dissertation). Lamar University, Beaumont. doi:10.4236/psych.2019.1011099

Altunısık, R., Coskun, R., Bayraktaroglu, S., \& Yıldırım, E. (2012). Sosyal bilimlerde araştırma yöntemleri [Research methods in social sciences.]. Adapazar1: Sakarya.

Arık, E. (2016) Geçmişten geleceğe Türk İşaret Dili araştırmaları [Turkish Sign Language studies from past to future]. In E. Arık (Ed.), Ellerle konuşmak: Türk Işaret Dili araştırmaları [Talking with hands: Turkish Sign Language research] (pp. 7-22). İstanbul: Koç Üniversitesi.

Arkonac, S. A. (2001). Sosyal psikoloji [Social psychology]. İstanbul: Alfa.

Aronson, E., Wilson, T. D., \& Akert, R. M. (2012). Social psychology. New Jersey: Pearson.

Bayley, R., Hill, J. C., McCaskill, C., \& Lucas, C. (2017). Attitudes towards black American Sign Language. University of Pennsylvania Working Papers in Linguistics, 23(2), 1-12. https://repository.upenn.edu/pwpl/vol23/iss2/4

Brightman, B. L. G. (2013). The relationship between attitudes and perspectives of American Sign Language university students towards deaf people. (Unpublished doctoral dissertation). University of South Florida, Florida. http://scholarcommons.usf.edu/etd/4868

Brown, T. A. (2006). Confirmatory factor analysis for applied research. New York: Guilford.

Bryman, A., \& Cramer, D. (1999). Quantitative data analysis with SPSS release 8 for Windows. London and New York: Taylor \& Francis e-Library, Routledge.

Buyukozturk, S. (2015). Sosyal bilimler için veri analizi el kitabı [Manual of data analysis for social sciences]. Ankara: Pegem.

Cambra, C. (2002). Acceptance of deaf students by hearing students in regular classrooms. American Annals of the Deaf, 147(1), 38-45. doi:10.1353/aad.2012.0138

Cengiz, D. U., Yayan, E. H., Ercan, M. K., Kolcu, D., \& Akgul, F. (2016, April). Isşitme engelli çocuklarda dil kazanımı ve konuşma eğitimi [Language acquisition and speech training in hearing impaired children]. Paper presented at the I. International Congress on Woman and Child Health and Training Conference, İstanbul.

Clark, M. D., Baker, S., Choi, S. H., \& Allen, T. E. (2013). The beliefs and attitudes about deaf education (BADE) scale: A tool for assessing the dispositions of parents and educators. Psychology, 4(12), 1030-1038. doi:10.1080/15348431.2018.1463848

Cohen, L., Manion, L., \& Morrison, K. (2011). Research methods in education. London: Routledge/Falmer. 
Cokluk, O., Sekercioglu, G., \& Buyukozturk, S. (2010). Sosyal bilimler için çok değişkenli istatistik: SPSS ve LISREL uygulamaları [Multivariate statistics for social sciences: SPSS and LISREL applications]. Ankara: Pegem.

Cooper, A., Rose, J., \& Mason, O. (2004). Measuring the attitudes of human service professionals toward deafness. American Annals of the Deaf, 148(5), 385-389. doi:10.1353/aad.2004.0001

Coryell, J., Holcomb, T. K., \& Scherer, M. (1992). Attitudes toward deafness: A collegiate perspective. American Annals of the Deaf, 137(3), 299-302. https://doi.org/10.1093/deafed/eny026

Erkus, A. (2003). Psikometri üzerine yazılar [Articles on psychometrics]. Ankara: Türk Psikologlar Derneği.

Erkus, A. (2012). Psikolojide ölçme ve ölçek geliştirme [Measurement and scale development in psychology]. Ankara: Pegem.

Field, A. P. (2009). Discovering statistics using SPSS. London, England: SAGE.

Fraenkel, J. R., \& Wallen, N. E. (2003). How to design and evaluate research in education. New York: McGraw-Hill.

Garson, G. D. (2009). Computerized simulation in the social sciences: A survey and evaluation. Simulation \& Gaming, 40(2), 267-279. doi:10.1177/1046878108322225

Gelbal, S., Duyan, V., \& Ozturk, A. B. (2008). Gender differences in sexual information sources, and sexual attitudes and behaviors of university students in Turkey. Social Behavior and Personality, 36(8), 1035-1052. http://dx.doi.org/10.2224/sbp.2008.36.8.1035

Girgin, M. C. (2006). İşitme engelli çocukların konuşma edinimi eğitiminde dinleme becerilerinin önemi [The importance of listening skills in hearing impaired children 'speech acquisition education]. Ankara Üniversitesi Eğitim Bilimleri Fakültesi Özel Eğitim Dergisi [Ankara University Faculty of Educational Sciences Journal of Special Education], 7(1), 15-28. doi:10.1501/Ozlegt_0000000096

Girgin, C., \& Kemaloglu, Y. (2017). İşitme yetersizliği olan çocuklara yönelik eğitim ortamları ve eğitimlerinde kullanılan iletişim yaklaşımları [Educational environments for children with hearing impairment and communication approaches used in their education]. In H. Gurgur \& P. Safak (Eds.), Isşitme ve görme yetersizliği [Hearing and vision impairment] (pp. 69-96). Ankara: Pegem.

Gol Guven, M. (2016). İşitme engelli olan çocukların Türk İşaret Dili (TİD) edinimini destekleyici eğitim malzemeleri geliştirme çalışması [Development of educational materials to support the hearing impaired children's Turkish Sign Language (TSL) acquisition]. In E. Arık (Ed.), Ellerle konuşmak: Türk Işsaret Dili araştırmaları [Talking with hands: Turkish Sign Language research] (pp. 445-4693). İstanbul: Koç Üniversitesi.

Gold-Schmidt, S. (2000). Einstellung gehörloser mit gehörlosen eltern zur deutschen gebärdensprache auf der grundlage von video-Interviews aus den jahren 1988 und 1999. (Unpublished master's thesis). University of Hamburg, Hamburg.

Goodwyn, S. W., Acredolo, L. P., \& Brown, C. A. (2000). Impact of symbolic gesturing on early language development. Journal of Nonverbal Behavior, 24(2), 81-103. https://doi.org/10.1023/A:1006653828895

Gorsuch, R. L. (1990). Common factor-analysis versus component analysis - Some well and little known facts. Multivariate Behavioral Research, 25(1), 33-39. doi:10.1207/s15327906mbr25013 
Gurboga, C., \& Kargın, T. (2003). İşitme engelli yetişkinlerin farklı ortamlarda kullandıkları iletişim yöntemlerinin/becerilerinin incelenmesi [Examining the communication methods/skills used by hearing impaired adults in different environments]. Journal of Faculty of Educational Sciences, 36(1), 51-64. doi:10.1501/Egifak_0000000074

Hair, J. F., Black, W. C., Babin, B. J., Anderson, R. E., \& Tatham, R. L. (1998). Multivariate data analysis. Upper Saddle River, NJ: Prentice Hall.

Haug, T., \& Hintermair, M. (2011). Einstellungen Studierender zu gehörlosen menschen und zu fragen der bildung gehörloser kinder. Teil I, Theoretische Überlegungen, methodisches Vorgehen und Vergleich von Einstellungen verschiedener studierendengruppen. Das Zeichen, 88, 234-45.

Hill, J. C. (2012). Language attitudes in the American Deaf Community. Washing-ton, DC: Gallaudet University.

Inceoglu, M. (2010). Attitude, perception, communication. İstanbul: Beykent University.

Isıkdogan-Ugurlu, N. (2017). İşitme engelli okuyucuların okuma sürecinde Türkçenin ve Türk İşaret Dilinin biçim-sözdizim özellikleri [Morpho-syntactic characteristics of Turkish and of Turkish Sign Language from the perspective of reading process of readers with hearing-impairment]. Ankara Üniversitesi Ĕ̈itim Bilimleri Fakültesi Özel Eğitim Dergisi [Ankara University Faculty of Educational Sciences Journal of Special Education], 18(2), 291-308. doi:10.21565/ozelegitimdergisi.288670

Jarvis, J., \& Iantaffi, A. (2006). 'Deaf people don't dance': Challenging student teachers' perspectives of pupils and inclusion. Deafness \& Education International, 8(2), 75-87. https://doi.org/10.1179/146431506790560184

Kagitcibas1, C. (2012). Günümüzde insan ve insanlar [People and people today]. Ankara: Evrim.

Kahyaoglu, M. (2011). Çevre konularıyla ilgili kitap okumaya yönelik tutum ölçeği geliştirme çalışması [Development study of attitude scale towards reading book about environmental issues]. İlköğretim Online [Elementary Education Online], 10(3), 1056-1065.

Kan, A. (2007). Öğretmen adaylarının eğitme-öğretme özyetkinliğine yönelik ölçek geliştirme ve eğitme-öğretme özyetkinlikleri açısından değerlendirilmesi (Mersin üniversitesi örneği) [Pre-service teachers' self-efficacy beliefs and assessing pre-service teachers' self-efficacy beliefs (The mersin university sample)]. Mersin Üniversitesi Ë̆itim Fakültesi Dergisi [Mersin University Journal of the Faculty of Education], 3(1), 35-50.

Kan, A., \& Akbas, A. (2005). A study of developing an attitude scale towards chemistry. Mersin University Journal of the Faculty of Education, 1(2), 227237. https://dergipark.org.tr/tr/pub/deubefd/issue/35753/399462

Karagoz, Y., \& Kosterelioglu, I. (2008). İletişim becerileri değerlendirme ölçeğinin faktör analizi metodu ile geliştirilmesi [Developing evaluation scale of communication skills with factor analysis]. Dumlupınar Üniversitesi Sosyal Bilimler Dergisi [Dumlupınar University Journal of Social Sciences], 21, 81-98. https://dergipark.org.tr/tr/pub/dpusbe/issue/4763/65440

Karasar, N. (2009). Bilimsel araştırma yöntemi [Scientific research method]. Ankara: Nobel.

Kemaloglu, Y. (2014). Engellilik, kulak burun boğaz (KBB) hekimliği ve işaret dili [Dysability, otorhinolaryngologic practice and sign langauge]. Bozok Tip Dergisi [Bozok Medical Journal], 1(1), 38-53. 
Kline, R. B. (2005). Methodology in the social sciences: Principles and practice of structural equation modeling. New York: Guilford.

Kubus, O., Ilkbasaran, D., \& Gilchrist, S. (2016). Türkiye'de işaret dili planlaması ve Türk İşaret Dilinin yasal durumu [Sign language in Turkey planning and legal status of Turkish Sign Language]. In E. Arık (Ed.), Ellerle konuşmak: Türk Işsaret Dili araştırmaları [Talking with hands: Turkish Sign Language research] (pp. 23-50). İstanbul: Koç Üniversitesi.

Lee, C., \& Pott, S. A. (2018). University students' attitudes towards deaf people: Educational implications for the future. Deafness \& Education International, 20(2), 80-99. doi:10.1080/14643154.2018.1438777

Leech, N. L., Barrett, K. C., \& Morgan, G. A. (2005). SPSS for intermediate statistics: Use and interpretation. Lawrence Erlbaum Associates, Publishers, Mahwah, New Jersey, London.

Ministry of National Education [Milli Eğitim Bakanlı̆̆g]. (2016). İşaret dili dersi ögretim programı [Sign language curriculum]. Retrieved from 18 March 2020, http://orgm.meb.gov.tr/www/turk-isaret-dili-dersiogretimprogramiyururlukte/içerik/766.

Moore, B., Acredolo, L., \& Goodwyn, S. (2001). Symbolic gesturing and joint attention: Partners in facilitating verbal development. Paper presented at the Biennial Meeting of the Society for Research in Child Development. Minneapolis, USA.

Morgan, C. T. (1991). Psikolojiye giriş [Introduction to psychology]. Ankara: Hacettepe Üniversitesi Psikoloji Bölümü.

Most, T., Aram, D., \& Andorn, T. (2006). Early literacy in children with hearing loss: A comparison between two educational systems. The Volta Review, 106(1), 5-28.

Ozbay, M., Bagcı, H., \& Uyar, Y. (2008). Türkçe öğretmeni adaylarının okuma alışkanlığına yönelik tutumlarının çeşitli değişkenlere göre değerlendirilmesi [Evaluation of the preservice Turkish teachers' attitudes towards reading habit according to some variables]. Inönü Üniversitesi Eğitim Fakültesi Dergisi [Inonu University Journal of the Faculty of Education], 9(15), 117-136. https://dergipark.org.tr/tr/pub/inuefd/issue/8708/108719

Parlak, S. (2011). Türkiye'deki işitme engelliği ve işletmelerdeki danışmanlık hizmetleri üzerine bir pilot çalışma [A pilot study on the hearing impairment and business consulting services in Turkey]. Bursa: Ekin.

Pistav Akmese, P., \& Kayhan, N. (2016). Opinions and suggestions of preschool teachers regarding educational games and their use in inclusive settings. SDU International Journal of Educational Studies, 3(1), 45-58.

Pistav Akmese, P., \& Kayhan, N. (2017). Examination of Turkish sign language education according to the opinions of preservice teachers who attend to the sign language course. Turkish Online Journal of Qualitative Inquiry, 8(1), 1-38. doi:10.17569/tojqi.280054

Reid, N. (2006) Thoughts on attitude measurement. Research in Science \& Technological Education, 24(1), 3-27. doi: 10.1080/02635140500485332

Sar1, H. (2007). The influence of an in-service teacher training (INSET) programme on attitudes towards inclusion by regular classroom teachers who teach deaf students in primary schools in Turkey. Deafness \& Education International, 9(3), 131-146. https://doi.org/10.1179/146431507790559996

Schermelleh-Engel, K., Moosbrugger, H., \& Muller, H. (2003). Evaluating the fit of structural equation models: Tests of significance and descriptive goodness-of-fit measures. Methods of Psychological Research Online, 8(2), 23-74. 
Secer, I. (2013). Spss ve Lisrel ile pratik veri analizi [Practical data analysis with Spss and Lisrel]. Ankara: An1.

Seker, H., Deniz, S., \& Gorgen, I. (2004). Öğretmen yeterlikleri ölçeği [Teacher competencies scale]. Milli Eğitim Dergisi [National Education Journal], 164, $105-118$.

Senay, Y. (2004). Çocukta dil gelişimi [Language development in child]. International Journal of Human Sciences, 1(1), 1-17.

Stokoe, W. C. (2005). Sign language structure: An outline of the visual communication systems of the American deaf. Journal of Deaf Studies and Deaf Education, 10(1), 3-37. doi:10.1093/deafed/eni001

Tabachnick, B. G., \& Fidell, L. S. (2001). Using multivariate statistics. New York: Harper \& Row.

Tavsanc1l, E. (2010). Tutumların ölçülmesi ve SPSS ile veri analizi [Measuring attitudes and data analysis with SPSS]. Ankara: Nobel.

Thompson, B. (2004). Exploratory and confirmatory factor analysis: Understanding concepts and applications. Washington, DC: American Psychological Association.

Ting, C., \& Gilmore, L. (2012). Attitudes of preservice teachers towards teaching deaf and ESL students. Australian Journal of Teacher Education, 37(12), 2-23. http://dx.doi.org/10.14221/ajte.2012v37n12.6

Topbas, S. (2003). Dil gelişiminin sosyal temelleri [Social foundations of language development]. In S. Topbas (Ed.), Çocukta dil ve kavram gelişimi [Language and concept development in child] (pp. 75-92). Eskişehir: Anadolu Üniversitesi Açıöŏretim Fakültesi.

Tufekcioglu, U. (2001). Dil gelişiminde sorunlara neden olan engeller [Barriers that cause problems in language development]. In S. Topbas (Ed.), Çocukta dil ve kavram gelişimi [Language and concept development in child] (pp. 185-209). Eskişehir: Anadolu Üniversitesi Açıöŏgretim Fakültesi.

Ulgen, G. (1996). Eğitim psikolojisi [Education psychology]. Ankara: Lazer.

Uzuner, Y. (2003). İşitme engelli çocuklarda erken dil gelişimi [Early language development in hearing impaired children]. In U. Tufekcioglu (Ed.), İsitme, konuşma, görme sorunları olan çocukların eğitimi [Education of children with hearing, speech, vision problems] (pp. 97-118). Eskişehir: Anadolu Üniversitesi Açıköğretim Fakültesi.

Varinli, I., Yaras, E., \& Basalp, A. (2009). Duygusal zekânın müşteri odaklılık ve satış performansı üzerine etkisini belirlemeye yönelik bir araştırma [A study for determining the impact of emotional intelligence on customer orientation and sales performance]. Ege Akademik Bakış [Ege Academic Review], 9(1), 113130. https://dergipark.org.tr/tr/pub/eab/issue/39855/472583

Wetson, R., \& Gore, P. A. (2006). A brief guide to structural equation model. The Counseling Psychologist, 34(5), 719-751.

Worthington, R. L., \& Whittaker, T. A. (2006). Scale development research a content analysis and recommendations for best practices. The Counseling Psychologist, 34(6), 806-838. https://doi.org/10.1177/0011000006288127

Yaprak Kemaloglu, P. (2016). Sağır ve ilgili paradigmaların biyolojik, politik ve sosyokültürel inşası [Biological, political and socio-cultural construction of deaf and related paradigms]. In E. Arık (Ed.), Ellerle konuşmak: Türk Işsaret Dili araştırmaları [Talking with hands: Turkish Sign Language research] (pp. 115140). İstanbul: Koç Üniversitesi. 